\title{
The Coverage of Augusta 109 Naval Helicopter Crash In Bayelsa State by Three Nigerian Newspapers: The Depth, Disposition and Pattern
}

\author{
Godwin B. Okon
}

\begin{abstract}
The thrust of this study was predicated on the need to analyze the nature of coverage given to the Augusta 109 naval helicopter crash by The Tide. The Punch and The Nation newspapers with a view to streamlining depth and pattern. The primary objective was to infer the disposition of the newspapers towards the crash, in the light of inexplicable air crashes in Nigeria, as highlighted through news contextualization within the parameters of advocacy journalism. The study necessitated content analysis. Fifteen (15) issues of the newspapers were selected and studied using the constructed calendar as a frame. Inter-coder reliability showed a correlation of 0.82 . Quantitative analysis was done using newshole as measured in column centimeters while qualitative analysis was done using the Constant Comparative Technique. Findings revealed that out of a total newshole of $829,783 \mathrm{col}$. cms, the papers allotted only about four percent to the incident. Findings further revealed an abysmal output by the newspapers in terms of depth with no editorial on the issue. Qualitative analysis showed a non-proactive disposition towards advocacy. It was therefore recommended that there should be an awakening by the Nigerian press to enrich reports with depth while being proactively disposed towards advocacy journalism with a view to according animation to its watchdog role.
\end{abstract}

Key words: *Advocacy *Coverage *Depth *Disposition *Pattern

\section{Overview}

The cultural norms typology enjoins the mass media to give an account of the day's events in a context that gives them meaning. In other words, the mass media ought to serve as the repertoire of information needed to advance knowledge through rational discourse.

Information as contextualized above is key and central to all forms of activities in humanistic settings. Every individual needs information to adapt knowledgably to the society while reacting intelligently to the environment. The surveillance function of the mass media finds expression in the foregoing. Surveillance in this context relates to the constant flow of public information or news about events occurring within the country and in the world. The news and information role of the mass media make them the watch dog and sentinel of society.

According to Kamat (2011), the surveillance function of the mass media can be divided into two types;

Warning or beware surveillance which occurs when the media inform us about threats from weather changes, war, cyclones etc; while instrumental surveillance occurs when the information useful in everyday life is transmitted (p.13)

When news is properly reported in the order of the $5 \mathrm{Ws} \& \mathrm{H}$, the reader does not only stand to benefit from the on-the-spot assessment of the situation but also stands to gain a full understanding of the ultimate meaning and significance of events.

From a kaleidoscope of events in 2012, Nigerians were thrown into shock and bewilderment on the $15^{\text {th }}$ of December as news of the Augusta 109 helicopter crash that killed General Andrew Azazi, the former National Security Adviser, Patrick Yakowa, the then Governor of Kaduna State and four others filtered through the air waves. As would be expected, going by the limitations of electronic media news report, the news strips were brief and unarguably skeletal thus perpetuating the anguish, suspense and curiosity of many Nigerians.

Worth noting is the fact that the print media have a proclivity for details in contradistinction to the electronic media. Through editorial and opinion (op.ed) pages, the print media are naturally positioned to illuminate perspectives on topical issues and events.

Niles(2011) however notes that "the only way journalists can serve the community better is to become advocates for the truth and this entails calling attention to absurdities in the society"(p.27).

Drawing from the foregoing parameters as encapsulated in the surveillance framework, the coverage of the Augusta 109 naval helicopter crash by the Nigerian press should not leave readers in doubt as to what happened, how it happened and why it happened coupled with suggestions on how to avert a recurrence within the ambits of avoidable air disasters. It is however incontrovertible that the coverage given to an issue by the mass media, especially the print, gives an insight into the disposition of the media concerning that issue. 
Deductively, therefore, the disposition of the Nigerian press as illuminated through its coverage of the helicopter crash forms the thrust of this study.

\section{The Setting}

Bayelsa State is one of the six states that make up Nigeria's south - South geo-political zone. It has interstate boundaries with Rivers state to the west and north-west, Delta state to the east and south-east. The gulf of Guinea lies to its south with yenegoa as its capital.

The state was created in 1996 from part of Rivers state. Bayelsa state has one of the largest crude oil and natural gas deposits in Nigeria. It has a riverine and estuarine setting. Most of the communities are surrounded by water thereby making them inaccessible by road. Its total area space is about 21,110 sq.km. According to 2006 census figures, the state has a population of about $1,998,349$. The people are mainly of the Ijaw ethnic stock.

\section{The Tragedy}

Governor Patrick Yakowa of Kaduna state and General Andrew Azazi, former National Security Adviser(NSA) were among the many dignitaries who attended the burial of the father of Oronto Douglas, a Senior Special Assistant to the President on Research and Documentation. The funeral took place in the Nembe area of Bayelsa state on the $15^{\text {th }}$ of December, 2012.

The Augusta 109 helicopter was one of several helicopters that ferried the political class as well as other dignitaries to the funeral. The helicopter crashed ten minutes after take-off while travelling from the venue of the funeral to Portharcourt, the capital of Rivers state, where the passengers were expected to board a flight to Abuja, the Federal capital. Governor Yakowa and General Azazi as well as four other passengers aboard the helicopter were burnt to ashes in that crash. This is the third Augusta 109 lost by the Nigerian navy out of a fleet of six helicopters since 2006.

\section{The Problem}

Contemporary events bearing international dimensions reveal that air crash investigations are often driven by a genuine quest to make the air space safer and air equipment better. The propensity for this is matched by an indepth analysis of what led to the crash and how such fatalities can be avoided in future. The role of the media in this regard becomes quite indispensable.

The Nigerian air space has in recent times witnessed disasters quite difficult to fathom. According to Orji (2012),

On October, 22, 2005 Bellview airlines Boeing 737 carrying 117 people on board crashed at Lissa Ogun State soon after take off from Lagos, it killed everyone on board. On December 10, 2005, a Sosoliso DC 9 crashed at the Port Harcourt international air port killing 103 people on board. On October, 29, 2006, an ADC Boeing 737 flight from Abuja to Sokoto crashed killing 106 out of 114 people on board. On June 3, 2012, a Dana Aircraft from Abuja to Lagos crashed into residential buildings in Iju, Lagos Killing 152 people on board.(p.43)

Most recently was the Augusta 109 naval helicopter crash of $15^{\text {th }}$ December, 2012, involving the Kaduna State governor, Patrick Yakowa and the former National Security Adviser, Gen. Andrew Azazi alongside their pilots and aides, thus inciting palpable fears in the hearts of many Nigerians concerning the safety of our air waves.

The incomprehensibility of the spate of air crashes in Nigeria is indeed a yawning gap. It is however expected that media reports should proffer answers to probing/throbbing questions that streamline causality. In other words, media reports should illuminate whether these crashes, particularly that of December 2012 occurred due to non compliance with aviation rules or lack of inspection and monitoring of air line operators to ensure compliance with maintenance regimes. More descriptively so, it is expected that media reports, when condensed, should extrapolate if the foregoing crashes, especially the December 2012, were borne out of man made errors or worst case scenario be described as unavoidable acts of fate.

Where the records are not so made available to the media, it still falls within the purview of journalism ideals that advocacy be made concerning the handling of air crash investigations in Nigeria. This is the beauty of journalism when viewed within the context of pointing out needs and proffering solutions.

How the media, especially newspapers, have fared in this regard is the primary concern of this study. In other words, do print media reports on air crashes in Nigeria illuminate probable causes of these crashes and remedies? When efforts to get these details from cognate agencies fail, do the media especially newspapers, employ the tools of advocacy to call attention to these anomalies? The problem of this study is therefore preconceived in the foregoing.

\section{The objectives}

The objectives of this study revolve around the need to;

1) examine, through content, the depth of coverage given to Augusta 109 naval helicopter crash by the three newspapers studied.

2) Streamline the disposition of the three newspapers towards the crash as highlighted through news contextualization and presentation within the parameters of advocacy journalism 
3) Infer from the above, the pattern of coverage, as marked by volume and frequency, given to the helicopter crash by the three newspapers studied

\section{Research Questions}

1) To what extent did the three newspapers display depth in the coverage of Augusta 109 naval helicopter crash?

2) To what extent were the three newspapers proactively disposed towards details concerning the crash and the need to avert future crashes?

3) What patterns did the newspapers assume in terms of volume and frequency of coverage?

\section{Operationalization of Terms}

- Advocacy journalism- The form of journalism that draws attention to a cause or ideology

- Contextualization- Story theme as marked by soft, hard or opinionated in terms of editorial, features etc

- Coverage - Reportage of an event

- Depth - News reports that contain all the details about the 5Ws and H

- Disposition - The stand point of a newspaper measured in terms of reporting the news as it is and going beyond the ordinary to crusade for a cause of action

- Frequency - The number of times a story appears in a newspaper

- News - An account of an event and not the event itself

- Pattern - Style of coverage as demonstrated through news space, treatment and frequency

- Presentation - Placement of stories in straight news or interpretation

- Volume - Total news hole devoted to a story

\section{Review of Literature}

Kwansah- Aidoo (2003) in an exploratory study affirmed that news and general media coverage of issues and events impact significantly on public opinion. Media coverage unequivocally is akin to perception since coverage can set an agenda and can also alter public perceptions of the players in the process depending on the type of coverage.

The agenda setting function of the press is therefore predicated upon the belief that the media only tell people what to think about. Agenda setting scholars (McCombs and Estrada, 1997) postulate that beyond merely providing cues about the salience of certain topics and issues, the mass media also tell people how to think about these topics and issues. This according to Rogers and Dearing (1997) is done by way of framing which is referred to as "a second dimension of agenda setting" (p. 246).

Contemporary media studies tend to focus on the way the mass media employ the techniques of news reporting to represent reality. Shoemaker and Reese (1996) suggest that the mass media transmit much more than just information and accurate facts. The media content takes elements from the environment, magnifies them, frames them and feeds them back to an audience thus imposing their logic in creating a "symbolic environment" (p. 60).

In their analysis of the role of the media in the understanding of reality, the authors used Lippman's concept of stereotypes to emphasise the important distinction between "reality and social reality"- that is as Lippman termed it "the world outside" of actual events and our mediated knowledge of those events.

Shoemaker and Reese (1996) further contend that we depend on secondhand sources for our knowledge about that part of the world beyond our immediate perceptual grasp. "Our perceptions of an object or event are at the mercy of the accuracy and completeness of those sources "(p. 39).

Chong and Druckman(2007) hold that when covering political issues, the news media do more than provide the facts, they also provide frames that tell readers how to understand the issues at stake.

In his study, framing, media bias and political power, Entman (2007) demonstrated how agenda setting, framing and priming fit together as tools of definition while explaining news slants and the phenomenon of bias.

Media reports are the products of the work of journalists who are often influenced by their own system of beliefs and by the network of Ideological and corporate pressures that have been documented to wield influence on the journalistic process (Wolfe, 1983, Chomskey, 1985). It has been averred that mass media content - both news and entertainment- is shaped, pounded, constrained and encouraged by a multiple of forces.

Stromback, Karrison and Hopman (2012) have in a study noted that there may be many factors aside from news values or criteria of newsworthiness that determine what becomes news and that there may also be differences between what journalists think should be and actually is important when deciding what news is.

Across board, we need news to live our lives, to protect ourselves, bond with each other, identify threats and opportunities. Kovach and Rosential (2006) note that journalism is simply the system societies generate to supply this news. 
Noteworthy is the fact that the character of news and journalism we get influences the quality of our lives, our thoughts and our culture. The general concern over the style of journalism that serves societal needs and purpose is inherently justified by the foregoing premise.

\section{Methodology}

The peculiarities of this study necessitated a content analysis. This method according to Kerlinger (2000) "studies and analyzes mass media content in a systematic, objective and quantitative manner for the purpose of measuring variables"(p.67). The justification for this method according to Wimmer and Dominick (2005) is embedded in its ability to "identify trends over long periods of time" (p. 142).

Descriptively, the study entailed an analysis of the content of three Nigerian newspapers from December 16 to December 31,2012, with a view to synthesizing the direction of coverage the helicopter crash received. The period of study as highlighted above was considered appropriate and cognate based on freshness and timeliness as core news values.

The three newspapers studied- The Nation, Punch and Tide - were purposively selected based on editorial posture and regional dominance. In other words, The Nation and Punch newspapers were selected based on their posture as national dailies while Tide was selected as a regional newspaper with the South- South region as its area of dominant influence. This is significant drawing from the fact that the South-South region was the scene of incident -helicopter crash.

By extrapolation, the population for the study stood at thirty-eight (38) issues of the three newspapers bearing in mind the period of study -16 days. By disaggregation, the national dailies had sixteen issues each, within the study period, while Tide had six (6) issues being a thrice-weekly newspaper.

Fifteen (15) issues of the newspapers were sampled and studied using a composite method as outlined in the constructed calendar. According to Riffe, Aust and Lacy (1991), a composite week sampling technique is superior to a random sample when dealing with newspapers.

Specifically, for The Nation and The Punch, the issues that fell on 16, 18, 20, 22, 24 and 28 December were selected and sampled based on the method outlined above while for The Tide the issues that fell on 17, 19 and 21 December were also selected and studied.

The procedure for analysis consisted of an operationalization of the subject matter. To this end the subject matter was defined thus, "any news story, straight or interpretative that was devoted to the Augusta 109 naval helicopter crash with implicit or explicit reference to Gen. Andrew Azazi, Patrick Yakowa, their aides and the pilots as well as other previous air crashes in Nigeria".

Measurement was carried out for news content that fell within the purview of the foregoing definition. As a corollary, advertorials in the form of Public Service Announcements (PSAs) by the newspapers were also incorporated and studied bearing in mind the fact that advertorials naturally lend themselves to advocacy.

News space was measured in column centimeter and this formed the basis for quantitative analysis. Based on the foregoing, coding of content into categories was made along the lines of straight news, editorial, features and advertorial.

Analyses on depth and disposition were done qualitatively using the Constant Comparative Technique (CCT) developed by Glaser and Strauss (1967) and modified by Lincoln and Guber (1985).

To ensure reliability and researcher non bias with a view to reducing the margin of error while widening the limit of accuracy, a professional coder was employed to assist in the coding.

A total of 120 items were categorized. Based on the categorization, the coders agreed on 98 categories and disagreed on 22 categories. Differences in coding were correlated using Holsti (1968) formula:

\section{$\underline{2(\mathrm{C} 1.2)}$}

$\mathrm{C} 1+\mathrm{C} 2$

$\mathrm{C} 1.2=$ Number of category assignments agreed on

$\mathrm{C} 1+\mathrm{C} 2=$ Total number of category assignments made by both coders

$\mathrm{r} \quad=$ Correlation

$=2(98)$

$=120+120$

$=\underline{2 \times 98}$

240

$=\underline{196}$

240

$=0.82$

The computation shows a high correlation which no doubt holds validation for the coding categories. 
Data Presentation

Table 1

Content distribution in TheTide newspaper

\begin{tabular}{|c|c|c|}
\hline Content & $\begin{array}{c}\text { Allocation of space in } \\
\text { column centimeters }\end{array}$ & Space in percentage \\
\hline Straight news & 44253 & 55.0 \\
\hline Editorial & 1326 & 1.6 \\
\hline Features & 8346 & 10.4 \\
\hline Advertorial & 12060 & 15.0 \\
\hline Sports & 14508 & 18.0 \\
\hline Total & $\mathbf{8 0 4 9 3}$ & $\mathbf{1 0 0}$ \\
\hline
\end{tabular}

Table 1 shows a total news hole of 80,493 col.cms out of which $55 \%$ was dedicated to straight news and $10 \%$ to features.

Table 2

Content distribution in The Punch newspaper

\begin{tabular}{|c|c|c|}
\hline Content & $\begin{array}{c}\text { Allocation of space in column } \\
\text { centimeters }\end{array}$ & Space in percentage \\
\hline Straight news & 182125 & 46.7 \\
\hline Editorial & 3817 & 1.0 \\
\hline Features & 41607 & 10.7 \\
\hline Advertorial & 141869 & 36.4 \\
\hline Sports & 20448 & 5.2 \\
\hline Total & $\mathbf{3 8 9 8 6 6}$ & $\mathbf{1 0 0}$ \\
\hline
\end{tabular}

Table 2 highlights content distribution in punch. Data no doubt shows relative convergence with newshole distribution in Tide.

Table 3

Content distribution in The Nation newspaper

\begin{tabular}{|c|c|c|}
\hline Content & $\begin{array}{c}\text { Allocation of space in column } \\
\text { centimeters }\end{array}$ & Space in percentage \\
\hline Straight news & 224640 & $62.5 \%$ \\
\hline Editorial & 5616 & $1.6 \%$ \\
\hline Features & 36504 & $10.1 \%$ \\
\hline Advertorial & 64584 & $18.0 \%$ \\
\hline Sports & 28080 & $7.8 \%$ \\
\hline Total & $\mathbf{3 5 9 4 2 4}$ & $\mathbf{1 0 0}$ \\
\hline
\end{tabular}

Data in Tables 1 and 2 apply with a slight preponderance for straight news in The Nation newspaper as shown above.

Table 4

News space allotted to the helicopter crash by The Tide

\begin{tabular}{|c|c|c|c|c|c|}
\hline \multirow[t]{2}{*}{ Content } & \multicolumn{4}{|c|}{ Allocation of space in column centimeters } & \multirow{2}{*}{$\begin{array}{ll}\text { Space } & \text { in } \\
\text { percentage }\end{array}$} \\
\hline & D1 & D2 & D3 & Total & \\
\hline Straight news & 324 & 640 & 1567 & 2531 & $3.8 \%$ \\
\hline Editorial & 0 & 0 & 0 & 0 & 0 \\
\hline Features & 0 & 0 & 0 & 0 & 0 \\
\hline Advertorial & 0 & 0 & 0 & 0 & 0 \\
\hline
\end{tabular}

Of a total news space of 65,985 col.cms, TheTide newspaper devoted only about four percent to the helicopter crash. Quantification of space took into cognizance the fact that sports stories do not lend themselves to the reportage of issues. Advertorial on its own allows for advocacy in terms of public service announcements (PSAs).

Table 5

News space allotted to the helicopter crash byThe Punch

\begin{tabular}{|l|l|l|l|l|l|l|l|l|}
\hline \multirow{2}{*}{ Content } & \multicolumn{6}{|c|}{ Allocation of space in column centimeters } & $\begin{array}{l}\text { Space in } \\
\text { percenta } \\
\text { ge }\end{array}$ \\
\cline { 2 - 10 } & D1 & D2 & D3 & D4 & D5 & D6 & Total \\
\hline Straight news & 3628 & 2194 & 3057 & 335 & 108 & 491 & 9,813 & $2.6 \%$ \\
\hline
\end{tabular}


The Coverage Of Augusta 109 Naval Helicopter Crash In Bayelsa State By Three Nigerian:

\begin{tabular}{|l|l|l|l|l|l|l|l|l|}
\hline Editorial & 0 & 0 & 0 & 0 & 0 & 0 & 0 & 0 \\
\hline $\begin{array}{l}\text { Features/Letters } \\
\text { to the Editor }\end{array}$ & 468 & 24 & 442 & 0 & 0 & 0 & 934 & $0.2 \%$ \\
\hline Advertorial & 0 & 0 & 0 & 0 & 0 & 0 & 0 & 0 \\
\hline
\end{tabular}

$\mathbf{N}=369,418$ col.cms

By approximation, about three percent of its total news space was allotted to the helicopter crash by Punch with straight news as the predominant genre.

Table 6

News space allotted to the helicopter crash by The Nation

\begin{tabular}{|c|c|c|c|c|c|c|c|c|}
\hline \multirow[t]{2}{*}{ Content } & \multicolumn{7}{|c|}{ Allocation of space in column centimeters } & \multirow{2}{*}{$\begin{array}{l}\text { Space in } \\
\text { percentag } \\
\text { e }\end{array}$} \\
\hline & D1 & D2 & D3 & D4 & D5 & D6 & Total & \\
\hline Straight news & 5644 & 3419 & 2840 & 0 & 0 & 0 & 11903 & $3.4 \%$ \\
\hline Editorial & 0 & 0 & 0 & 0 & 0 & 0 & 0 & 0 \\
\hline $\begin{array}{l}\text { Features/Letters } \\
\text { to the Editor }\end{array}$ & 468 & 468 & 240 & $\begin{array}{l}43 \\
34\end{array}$ & 0 & 0 & 5510 & $1.7 \%$ \\
\hline Advertorial & 0 & 0 & 0 & 0 & 0 & 0 & 0 & 0 \\
\hline
\end{tabular}

$\mathbf{N}=331,344$ col.cms

The space allotted to the helicopter crash by the Nation did not differ significantly from that of Punch. Interestingly, the features space witnessed upward allocation.

Table 7

Frequency and volume of news devoted to the crash by

\begin{tabular}{|l|l|l|l|l|}
\hline Categories & D1 & D2 & D3 & Total \\
\hline Straight & 324 & 640 & 1567 & 2531 \\
\hline Editorial & 0 & 0 & 0 & 0 \\
\hline Features & 0 & 0 & 0 & 0 \\
\hline Advertorial & 0 & 0 & 0 & 0 \\
\hline Total & 324 & 640 & 1567 & 2531 \\
\hline
\end{tabular}

The Tide

$\mathrm{N}=65,985$ col.cms

Table 7 shows consistency in terms of daily reportage while the volume of reportage was abysmal

Table 8

Frequency and volume of news devoted to the crash byThe Punch

\begin{tabular}{|l|l|l|l|l|l|l|l|}
\hline Categories & D1 & D2 & D3 & D4 & D5 & D6 & Total \\
\hline Straight & 3628 & 2194 & 3057 & 335 & 108 & 491 & 9813 \\
\hline Editorial & 0 & 0 & 0 & 0 & 0 & 0 & 0 \\
\hline Features & 468 & 24 & 442 & 0 & 0 & 0 & 934 \\
\hline Advertorial & 0 & 0 & 0 & 0 & 0 & 0 & 0 \\
\hline Total & 4096 & 2218 & 3499 & 335 & 108 & 491 & 10747 \\
\hline
\end{tabular}

$\mathbf{N}=369,418$ col.cms

There was consistency in daily reportage especially straight news with features showing a ratio of $1: 2$ in terms of frequency

Table 9

Frequency and volume of news devoted to the crash by The Nation

\begin{tabular}{|c|c|c|c|c|c|c|c|}
\hline Categories & D1 & D2 & D3 & D4 & D5 & D6 & Total \\
\hline Straight & 5644 & 3419 & 2840 & 0 & 0 & 0 & 11,903 \\
\hline Editorial & 0 & 0 & 0 & 0 & 0 & 0 & 0 \\
\hline Features & 468 & 468 & 240 & 4334 & 0 & 0 & 5510 \\
\hline Advertorial & 0 & 0 & 0 & 0 & 0 & 0 & 0 \\
\hline Total & 6112 & 3887 & 3080 & 4334 & 0 & 0 & 17413 \\
\hline
\end{tabular}

$\mathbf{N}=331,344$ col.cms

The Nation showed similarity in frequency with Tide with divergence revolving round features.

Legend D1 - D6 = Days 1 -6 


\section{Table 10a}

Contextualization and depth of news reports on helicopter crash by the three newspapers

\begin{tabular}{|c|c|c|c|c|c|c|c|c|c|c|c|}
\hline \multirow[t]{2}{*}{ Story type } & \multirow[t]{2}{*}{ Caption } & \multirow[t]{2}{*}{ Page } & \multicolumn{6}{|c|}{$5 W s \& H$} & \multirow{2}{*}{$\begin{array}{l}\text { Eye } \\
\text { witness/ } \\
\text { expert } \\
\text { account }\end{array}$} & \multirow[t]{2}{*}{ Advocacy } & \multirow[t]{2}{*}{ Newspaper } \\
\hline & & & Who & What & When & Where & Why & How & & & \\
\hline Straight news & $\begin{array}{l}\text { I regret not praying with him before } \\
\text { trip-Yaksoxa's, vife }\end{array}$ & $\begin{array}{l}1 \& \text { \& } \\
7\end{array}$ & $\mathrm{Y}$ & Y & $\mathrm{Y}$ & $\mathrm{Y}$ & $\mathrm{N}$ & $\mathrm{N}$ & $\mathrm{N}$ & $\mathrm{N}$ & $\begin{array}{l}\text { Punch } \\
\text { Dec. 16-12- } \\
2012\end{array}$ \\
\hline Photo new/5 & Wreckage of the crashed helicopter & 1 & $\mathrm{~N}$ & $\mathrm{Y}$ & $\mathrm{Y}$ & $\mathrm{Y}$ & $\mathrm{N}$ & $\mathrm{N}$ & $\mathrm{N}$ & $\mathrm{N}$ & \\
\hline Straight new/s & $\begin{array}{l}\text { New Kaduna gox., others eulogize } \\
\text { Yaksox/a }\end{array}$ & 7 & $\mathrm{Y}$ & $\mathrm{Y}$ & $\mathrm{Y}$ & $\mathrm{Y}$ & $\mathrm{N}$ & $\mathrm{N}$ & $\mathrm{N}$ & $\mathrm{N}$ & \\
\hline Straight news & $\begin{array}{l}\text { Yakpwa, Azazi's deaths shocking: } \\
\text { Sambo, Buhari, others }\end{array}$ & 8 & $\begin{array}{l}Y \\
Y\end{array}$ & $\bar{Y}$ & $\mathrm{Y}$ & $\mathrm{Y}$ & $\mathrm{Y}$ & $\mathrm{N}$ & $\mathrm{N}$ & $\mathrm{N}$ & \\
\hline Straight new/5 & $\begin{array}{l}\text { We are waiting for result of } \\
\text { investigation-Govs. }\end{array}$ & 12 & $\mathrm{Y}$ & $\bar{Y}$ & $\mathrm{Y}$ & $\mathrm{Y}$ & $\mathrm{N}$ & $\mathrm{N}$ & $\mathrm{N}$ & $\bar{Y}$ & \\
\hline Straight nev/5 & Death devastating- Mark, Tomobux,al & 12 & $\mathrm{Y}$ & $\mathrm{Y}$ & $\mathrm{Y}$ & $\mathrm{Y}$ & $\mathrm{N}$ & $\mathrm{N}$ & $\mathrm{N}$ & $\mathrm{N}$ & $n$ \\
\hline Straight new/5 & CAN mourns, calls for thorough probe & 12 & $\mathrm{Y}$ & $\mathrm{Y}$ & $\mathrm{Y}$ & $\mathrm{Y}$ & $\mathrm{N}$ & $\mathrm{N}$ & $\mathrm{N}$ & $\mathrm{Y}$ & n \\
\hline Straight new/s & Govs mourn Yakpox/a, Azazi & 13 & $\mathrm{Y}$ & $\mathrm{Y}$ & $\mathrm{Y}$ & $\mathrm{Y}$ & $\mathrm{Y}$ & $\mathrm{N}$ & $\mathrm{N}$ & $\mathrm{N}$ & " \\
\hline Straight new/5 & $\begin{array}{l}\text { Villagers recount moment of crashed } \\
\text { helicopter }\end{array}$ & 12 & $\bar{Y}$ & $\mathrm{Y}$ & $\mathrm{N}$ & $\bar{Y}$ & $\mathrm{~N}$ & $\mathrm{~N}$ & $\mathrm{Y}$ & $\mathrm{N}$ & \\
\hline Straight new/5 & $\begin{array}{l}\text { Dickson declares three day mourning; } \\
\text { weeps }\end{array}$ & 13 & $\mathrm{Y}$ & $\mathrm{Y}$ & $\mathrm{Y}$ & $\mathrm{Y}$ & $\mathrm{N}$ & $\mathrm{N}$ & $\mathrm{N}$ & $\mathrm{N}$ & \\
\hline Features & Gen. Azazi's final hour & 20 & $\mathrm{Y}$ & $\mathrm{Y}$ & $\mathrm{Y}$ & $\mathrm{Y}$ & $\mathrm{Y}$ & $\mathrm{N}$ & $\mathrm{Y}$ & $\mathrm{N}$ & n $\quad$ n \\
\hline Straight new/5 & $\begin{array}{l}\text { Helicopter crashed on } 15^{3} \text { trip of the } \\
\text { day-source }\end{array}$ & $\begin{array}{l}1 \& \\
2\end{array}$ & $\bar{Y}$ & $\mathrm{Y}$ & $\bar{Y}$ & $\bar{Y}$ & $\mathrm{~N}$ & $\mathrm{~N}$ & $\mathrm{Y}$ & $\mathrm{N}$ & $\begin{array}{c}\text { Punch } \\
18-12-2012\end{array}$ \\
\hline Straight new/5 & Govs. demand role in helicopter crash & 7 & $\mathrm{Y}$ & $\mathrm{Y}$ & $\mathrm{Y}$ & $\mathrm{Y}$ & $\mathrm{N}$ & $\mathrm{N}$ & $\mathrm{N}$ & $\mathrm{Y}$ & n \\
\hline Straight new/s & NBA calls for thorough investigation & 7 & $\mathrm{Y}$ & $Y$ & $\mathrm{Y}$ & $\mathrm{Y}$ & $\mathrm{N}$ & $\mathrm{N}$ & $\mathrm{N}$ & $\mathrm{Y}$ & $n$ \\
\hline Straight new/5 & We'll investigate Baxelsa Accident-Reps & 7 & $\mathrm{Y}$ & $Y$ & $\mathrm{Y}$ & $\mathrm{Y}$ & $\mathrm{N}$ & $\mathrm{N}$ & $\mathrm{N}$ & $\mathrm{Y}$ & " \\
\hline Straight new/5 & Yakowe's remains arrive Kaduna & 7 & $\mathrm{Y}$ & $\mathrm{Y}$ & $\mathrm{Y}$ & $\mathrm{Y}$ & $\mathrm{Y}$ & $\mathrm{N}$ & $\mathrm{N}$ & $\mathrm{N}$ & " \\
\hline Straight new/5 & $\begin{array}{l}\text { I didn't travel in crashed helicopter-VP } \\
\text { Samba }\end{array}$ & 7 & $\bar{Y}$ & $\mathrm{Y}$ & $\mathrm{Y}$ & $\bar{Y}$ & $\mathrm{~N}$ & $\mathrm{~N}$ & $\mathrm{~N}$ & $\mathrm{~N}$ & \\
\hline
\end{tabular}

Table 10b

Contextualization and depth of news reports on helicopter crash by the three newspapers

\begin{tabular}{|c|c|c|c|c|c|c|c|c|c|c|c|}
\hline \multirow[t]{2}{*}{ Story type } & \multirow[t]{2}{*}{ Caption } & \multirow[t]{2}{*}{ Page } & \multicolumn{6}{|c|}{$\mathrm{SWS}+\mathrm{H}$} & \multirow{2}{*}{$\begin{array}{l}\text { Eye } \\
\text { witness/ } \\
\text { expert } \\
\text { account }\end{array}$} & \multirow[t]{2}{*}{ Advocacy } & \multirow[t]{2}{*}{ Newspaper } \\
\hline & & & Who & What & When & Where & Why & How & & & \\
\hline Straight new/s & $\begin{array}{l}\text { Baxelsa crash: pilots family accuses } \\
\text { FG of partiality }\end{array}$ & $\begin{array}{l}1,4 \& \\
5\end{array}$ & $\mathrm{Y}$ & $\mathrm{Y}$ & $\bar{Y}$ & $\mathrm{Y}$ & $\mathrm{N}$ & $\mathrm{N}$ & $\mathrm{N}$ & $\mathrm{N}$ & $\begin{array}{ll}\text { Punch } & \\
\text { Dec. 20, } \\
2012\end{array}$ \\
\hline Straight new/s & $\begin{array}{l}\text { Yakowa's body arrives in Kaduna } \\
\text { amid tears }\end{array}$ & 2 & $\mathrm{Y}$ & $\mathrm{Y}$ & $\bar{Y}$ & $\bar{Y}$ & $\mathrm{~N}$ & $\mathrm{~N}$ & $\mathrm{~N}$ & $\mathrm{~N}$ & \\
\hline Straight news & NAILS boss decries air accidents & 12 & $\mathrm{Y}$ & $\mathrm{Y}$ & $\bar{Y}$ & $\mathrm{Y}$ & $\mathrm{N}$ & $\mathrm{N}$ & $\mathrm{N}$ & $\mathrm{Y}$ & n \\
\hline Straight new/s & $\begin{array}{l}\text { Senate orders probe into crashes, } \\
\text { demands past reports }\end{array}$ & 12 & $\mathrm{Y}$ & $\mathrm{Y}$ & $\bar{Y}$ & $\mathrm{Y}$ & $\mathrm{N}$ & $\mathrm{N}$ & $\mathrm{N}$ & $\mathrm{Y}$ & \\
\hline Straight new/5 & Yokpwa was detribalized-Dickson & 12 & $\mathrm{Y}$ & $\mathrm{Y}$ & $\bar{Y}$ & $\mathrm{Y}$ & $\mathrm{Y}$ & $\mathrm{N}$ & $\mathrm{N}$ & $\mathrm{N}$ & n \\
\hline Straight new/5 & $\begin{array}{l}\text { Presidency worries over gRx's } \\
\text { demand on crash probe }\end{array}$ & 13 & $\mathrm{Y}$ & $\mathrm{Y}$ & $\mathrm{Y}$ & $\mathrm{Y}$ & $\mathrm{N}$ & $\mathrm{N}$ & $\mathrm{N}$ & $\mathrm{N}$ & \\
\hline Straight news & $\begin{array}{l}\text { Don't sweep report under the } \\
\text { carpet-CAN }\end{array}$ & 13 & $\mathrm{Y}$ & $\mathrm{Y}$ & $\mathrm{Y}$ & $\bar{Y}$ & $\mathrm{~N}$ & $\mathrm{~N}$ & $\mathrm{~N}$ & $\mathrm{Y}$ & n \\
\hline Straight new/5 & Qbasanog, Alamesigha mourn & 13 & $\mathrm{Y}$ & $\mathrm{Y}$ & $\bar{Y}$ & $Y$ & $\mathrm{~N}$ & $\mathrm{~N}$ & $\mathrm{~N}$ & $\mathrm{~N}$ & n \\
\hline Features & $\begin{array}{l}\text { Qxiove Azazi: in the memory of the } \\
\text { living }\end{array}$ & 80 & $\mathrm{Y}$ & $\mathrm{Y}$ & $\mathrm{Y}$ & $\mathrm{Y}$ & $\mathrm{Y}$ & $\mathrm{N}$ & $\mathrm{Y}$ & $\mathrm{N}$ & n \\
\hline Straight news & $\begin{array}{l}\text { Azazi to receive state burial - } \\
\text { Dickson }\end{array}$ & 12 & $\mathrm{Y}$ & $\mathrm{Y}$ & $\mathrm{Y}$ & $\bar{Y}$ & $\mathrm{Y}$ & $\mathrm{N}$ & $\mathrm{N}$ & $\mathrm{N}$ & $\begin{array}{l}\text { Punch } \\
22-12-12\end{array}$ \\
\hline Straight new/s & $\begin{array}{l}\text { Why Azazi won't be buried in country } \\
\text { home }\end{array}$ & 15 & $\mathrm{Y}$ & $\mathrm{Y}$ & $\bar{Y}$ & $\bar{Y}$ & $\mathrm{Y}$ & $\mathrm{N}$ & $\mathrm{N}$ & $\mathrm{Y}$ & $\begin{array}{l}\text { Punch } \\
24-12-12\end{array}$ \\
\hline Photo news & $\begin{array}{l}\text { Remains of victims of helicopter } \\
\text { crash }\end{array}$ & 19 & $\mathrm{~N}$ & $\mathrm{Y}$ & $\bar{Y}$ & $\mathrm{~N}$ & $\mathrm{~N}$ & $\mathrm{~N}$ & $\mathrm{~N}$ & $\mathrm{~N}$ & $24-12-12$ \\
\hline Straight news & $\begin{array}{l}\text { How cleric rattled Jonathan, others } \\
\text { at Azazi's burial }\end{array}$ & 11 & $\mathrm{Y}$ & $\mathrm{Y}$ & $\mathrm{Y}$ & $\bar{Y}$ & $\mathrm{Y}$ & $\mathrm{N}$ & $\mathrm{N}$ & $\mathrm{Y}$ & $28-12-12$ \\
\hline Straight news & $\begin{array}{l}\text { Azazi preferred flying military } \\
\text { helicopters- Amaechi. }\end{array}$ & 13 & $\bar{Y}$ & $\bar{Y}$ & $\bar{Y}$ & $\mathrm{Y}$ & $\mathrm{N}$ & $\mathrm{N}$ & $\mathrm{N}$ & $\mathrm{N}$ & $28-12-12$ \\
\hline
\end{tabular}


Table 10c

Contextualization and depth of news reports on helicopter crash by the three newspapers

\begin{tabular}{|c|c|c|c|c|c|c|c|c|c|c|c|}
\hline \multirow[t]{2}{*}{ Story type } & \multirow[t]{2}{*}{ Caption } & \multirow[t]{2}{*}{ Page } & \multicolumn{6}{|c|}{ 5Tis\&H } & \multirow{2}{*}{$\begin{array}{l}\text { Eye ritimess/ } \\
\text { expert account }\end{array}$} & \multirow[t]{2}{*}{ Adrocacy } & \multirow[t]{2}{*}{ Nenspaper } \\
\hline & & & Who & What & When & Where & Why & How & & & \\
\hline Straght narwo & $\begin{array}{l}\text { Yalowa's Deputy strom-in as Gov. } \\
\text { Amsechi, others moum }\end{array}$ & $1 \& 2$ & $\bar{Y}$ & $Y$ & $Y$ & $Y$ & $\mathrm{~N}$ & $\mathrm{~N}$ & $Y$ & $\mathrm{~N}$ & $\begin{array}{c}\text { Tide } \\
\text { 17-12-2012 }\end{array}$ \\
\hline Straight narwo & $\begin{array}{l}\text { Yaloora for burial morrow; Bayelas } \\
\text { holds valedictory sassion }\end{array}$ & $1 \& 2$ & $Y$ & $Y$ & $Y$ & $Y$ & $\mathrm{~N}$ & $\mathrm{~N}$ & $\mathrm{~N}$ & $\mathrm{~N}$ & $\begin{array}{c}\text { Tide } \\
19-12 \cdot 2012\end{array}$ \\
\hline Photo Daxis & $\begin{array}{l}\text { Wife of the vice president with the first } \\
\text { lasy's risit to the byeaved tzmilies }\end{array}$ & 7 & $\bar{N}$ & $\mathrm{~N}$ & $\mathrm{~N}$ & $\mathrm{~N}$ & $\mathrm{~N}$ & $\mathrm{~N}$ & $\mathrm{~N}$ & $\mathrm{~N}$ & \\
\hline Straight narus & Tributes, teas as Yaloorra is buied & $1 \& 2$ & $Y$ & $Y$ & $Y$ & $Y$ & $Y$ & $Y$ & $\mathrm{~N}$ & $\mathrm{~N}$ & $\begin{array}{c}\text { Tid? } \\
21-12-2012\end{array}$ \\
\hline Straight naws & Yaloorra ras a bridge brildder Dickson & 5 & $Y$ & $Y$ & $Y$ & $Y$ & $Y$ & $Y$ & $\mathrm{~N}$ & $\mathrm{~N}$ & \\
\hline Straght narwo & $\begin{array}{l}\text { Senate, invertigates resurgence of air } \\
\text { mishaps }\end{array}$ & 19 & $\bar{Y}$ & $Y$ & $Y$ & $Y$ & $Y$ & $\mathrm{~N}$ & $\mathrm{~N}$ & $Y$ & \\
\hline Strieght axwo & Crash, a monumental tragady Dickson & 19 & $Y$ & $Y$ & $Y$ & $Y$ & $Y$ & $\mathrm{~N}$ & $\mathrm{~N}$ & $\mathrm{~N}$ & \\
\hline Straight naxw & $\begin{array}{l}\text { Yaloorais desth: NGF suppots call for } \\
\text { investigation }\end{array}$ & 19 & $\bar{Y}$ & $Y$ & $\bar{Y}$ & $\bar{Y}$ & $Y$ & $\bar{N}$ & $\mathrm{~N}$ & $Y$ & \\
\hline Straight naw" & $\begin{array}{l}\text { FAAN set to remove abandonad gir } \\
\text { craf's from Aiponts }\end{array}$ & 19 & $\bar{N}$ & $Y$ & $Y$ & $Y$ & $\mathrm{~N}$ & $\bar{N}$ & $\mathrm{~N}$ & $\mathrm{~N}$ & \\
\hline Strieght naws & Senste probas military halicopters use & 32 & $Y$ & $Y$ & $Y$ & $Y$ & N & $\mathrm{N}$ & $\mathrm{N}$ & $\mathrm{N}$ & $"$ \\
\hline
\end{tabular}

Table 10d

Contextualization and depth of news reports on helicopter crash by the three newspapers

\begin{tabular}{|c|c|c|c|c|c|c|c|c|c|c|c|}
\hline \multirow[t]{2}{*}{ Story type } & \multirow[t]{2}{*}{ Caption } & \multirow[t]{2}{*}{ Page } & \multicolumn{6}{|c|}{ SWS $+\mathrm{H}$} & \multirow{2}{*}{$\begin{array}{l}\text { Eye witness } \\
\text { expert } \\
\text { account }\end{array}$} & \multirow[t]{2}{*}{ Advocacy } & \multirow[t]{2}{*}{ Newspaper } \\
\hline & & & Who & What & When & Where & Why & How & & & \\
\hline Straight news & $\begin{array}{l}\text { Yakowa, Azazi; puzzles in military circles over } \\
\text { crash }\end{array}$ & $\begin{array}{l}1 \& \\
2\end{array}$ & $Y$ & $\mathrm{~T}$ & $\mathrm{Y}$ & $Y$ & $\mathrm{Y}$ & $\mathbb{N}$ & $\mathrm{Y}$ & $\mathrm{N}$ & $\begin{array}{l}\text { The Nation } \\
16-12-2012\end{array}$ \\
\hline Straight news & $\begin{array}{l}\text { Augusta... the helicopter which threw Nigeris } \\
\text { into mourning }\end{array}$ & 7 & $\mathrm{Y}$ & $\mathrm{Y}$ & $\mathrm{Y}$ & $\mathrm{Y}$ & $\mathrm{N}$ & $\mathbb{N}$ & $\mathrm{Y}$ & $\mathbb{N}$ & \\
\hline Straight news & $\begin{array}{l}\text { Mark, Tambuwid, governors, probe crash of } \\
\text { Yakowa's, Azazi' schopper }\end{array}$ & 7 & $\mathrm{~T}$ & $\mathrm{~T}$ & $\mathrm{~T}$ & Y & $\mathrm{N}$ & $\mathrm{N}$ & $\mathrm{N}$ & Y & \\
\hline Straight news & $\mathrm{ACN}$ : their deaths must not be in vain & 7 & $\mathrm{Y}$ & $\mathrm{T}$ & $\mathrm{T}$ & $\mathrm{Y}$ & $\mathbb{N}$ & $\mathbb{N}$ & $\mathbb{N}$ & $\mathrm{Y}$ & \\
\hline Straight news & $\begin{array}{l}\text { NGO canvas ses uniform monitoring of aircraft, } \\
\text { helicopters }\end{array}$ & 7 & $\mathrm{Y}$ & $\mathrm{Y}$ & $\mathrm{Y}$ & $\mathrm{T}$ & $\mathrm{Y}$ & $\mathbb{N}$ & $\mathrm{N}$ & $\mathrm{y}$ & \\
\hline Straight news & Yakowa: Reations from Kaduna & 7 & $\mathrm{Y}$ & $\mathrm{T}$ & $\mathrm{Y}$ & $\mathrm{Y}$ & N & $\mathrm{N}$ & $\mathbb{N}$ & $\mathbb{N}$ & \\
\hline Straight news & $\begin{array}{l}\text { Azgzi's children recount their last dimer with } \\
\text { dad }\end{array}$ & $\begin{array}{l}1 \& \\
7\end{array}$ & $\mathrm{~T}$ & $\mathrm{Y}$ & $\mathrm{Y}$ & $\mathrm{Y}$ & $\mathbb{N}$ & $\mathbb{N}$ & $\mathbb{N}$ & $\mathbb{N}$ & $18-12-2012$ \\
\hline Straight news & Our agony, by parents of co-pilot Sowple & 1 & $\mathrm{Y}$ & $\mathrm{Y}$ & $\mathrm{Y}$ & $\mathrm{Y}$ & $\mathbb{N}$ & $\mathbb{N}$ & 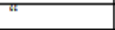 & " & \\
\hline Straight news & $\begin{array}{l}\text { Governor's seek transparency as Navynames } \\
\text { probe board }\end{array}$ & 7 & $Y$ & $Y$ & $Y$ & $Y$ & $N$ & $N$ & $\mathbb{N}$ & $\mathrm{y}$ & \\
\hline Straight news & First lady weeps as she visits Yakowa's widow & 8 & $\mathrm{Y}$ & $\mathrm{Y}$ & $\mathrm{Y}$ & $\mathrm{Y}$ & $\mathrm{N}$ & $\mathbb{N}$ & $\mathbb{N}$ & $\mathbb{N}$ & \\
\hline Straight news & Crash:NBA calls for probe & 12 & $\mathrm{Y}$ & $\mathrm{T}$ & $\mathrm{T}$ & $\mathrm{Y}$ & $\mathbb{N}$ & $\mathbb{N}$ & $\mathbb{N}$ & $\mathrm{Y}$ & 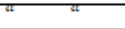 \\
\hline Straight news & Thesdigha Yug quda mourn crash victims & 12 & $\mathrm{Y}$ & $\mathrm{Y}$ & $\mathrm{Y}$ & $\mathrm{Y}$ & $\mathrm{N}$ & $\mathrm{N}$ & $\mathbb{N}$ & $\mathbb{N}$ & " \\
\hline Straight news & $\begin{array}{l}\text { Helicopter crash: Acting Governor condoles will } \\
\text { Jonathan, others }\end{array}$ & 12 & $\mathrm{~T}$ & $\mathrm{~T}$ & $\mathrm{~T}$ & $\mathrm{Y}$ & $\mathbb{N}$ & $\mathbb{N}$ & $\mathrm{N}$ & $\mathbb{N}$ & \\
\hline Straight news & Jonathan warns elders at Yakowa's funeral & 13 & $\mathrm{Y}$ & $\mathrm{Y}$ & $\mathrm{Y}$ & $\mathrm{Y}$ & $\mathrm{Y}$ & $\mathbb{N}$ & $\mathbb{N}$ & $\mathbb{N}$ & $20-12-12$ \\
\hline Straight news & $\begin{array}{l}\text { Our fathers death was God's will says Yalkowa's } \\
\text { son }\end{array}$ & 12 & $\mathrm{~T}$ & $\mathrm{~T}$ & $\mathrm{Y}$ & $\mathrm{Y}$ & $\mathbb{N}$ & $\mathrm{N}$ & $\mathbb{N}$ & $\mathbb{N}$ & \\
\hline Straight news & Dicks on: crashwas a tragedy & 13 & $\mathrm{Y}$ & $\mathrm{Y}$ & $\mathrm{Y}$ & $\mathrm{Y}$ & $\mathrm{N}$ & $\mathbb{N}$ & $\mathrm{N}$ & $\mathbb{N}$ & \\
\hline Straight news & Plane crash: Falang accuses Navy of sabotage & 13 & $\mathrm{Y}$ & $\mathrm{Y}$ & $\mathrm{Y}$ & $\mathrm{Y}$ & $\mathrm{N}$ & $\mathbb{N}$ & $\mathbb{N}$ & $\mathrm{Y}$ & " \\
\hline Features & $\begin{array}{l}\text { Yakowa/Azazi: Fate } 50 \text { implacable, so } \\
\text { inescapable }\end{array}$ & 20 & $\mathrm{Y}$ & $\mathrm{Y}$ & $\mathrm{Y}$ & $Y$ & $\mathrm{Y}$ & $\mathbb{N}$ & $\mathbb{N}$ & $\mathbb{N}$ & \\
\hline
\end{tabular}

Table 10 e

Contextualization and depth of news reports on helicopter crash by the three newspaper

\begin{tabular}{|c|c|c|c|c|c|c|c|c|c|c|c|}
\hline \multirow[t]{2}{*}{ Story type } & \multirow[t]{2}{*}{ Caption } & \multirow[t]{2}{*}{ Page } & \multicolumn{6}{|c|}{$\mathrm{SWS}+\mathrm{H}$} & \multirow{2}{*}{$\begin{array}{l}\text { Eye witness } \\
\text { expert } \\
\text { account }\end{array}$} & \multirow[t]{2}{*}{ Advocacy } & \multirow[t]{2}{*}{ Newspaper } \\
\hline & & & Who & What & When & Where & Why & How & & & \\
\hline Features & Suswam: Yakowa and Suntai & 22 & $\mathrm{Y}$ & $\mathrm{Y}$ & $\mathrm{Y}$ & $\mathrm{N}$ & $\mathrm{N}$ & $\mathrm{N}$ & $\mathrm{N}$ & N & $\begin{array}{l}\text { The Nation } \\
24-12-2012\end{array}$ \\
\hline Features & Is the airspace safe? & 27428 & $\mathrm{~N}$ & $\mathrm{~T}$ & $\mathrm{~N}$ & $\mathrm{~N}$ & $\mathrm{~N}$ & $\mathrm{~N}$ & $\mathrm{~N}$ & $\mathrm{~T}$ & \\
\hline Features & $\begin{array}{l}\text { Confirming Yakowa's death was big } \\
\text { challenge to reporters }\end{array}$ & 44 & Y & $\mathrm{Y}$ & Y & $\mathrm{Y}$ & $N$ & $\mathrm{~N}$ & $\mathrm{Y}$ & Y & \\
\hline
\end{tabular}

\section{Discussion}

The coverage given to the helicopter crash by the three newspapers studied was significantly shrift. This was further manifested by the fact that out of a total news hole of 829,783 col.cms the papers devoted only 
about four percent to the incident. Through disaggregation, it was further found that the predominant genre, across the three papers, in terms of news writing style, was the spot/straight news format. This format when viewed against the backdrop of topical issues often leaves readers in a state of passivity and makes them unable to contribute to rational discourse since it does not arm them with cognate details about an issue.

Findings further revealed an abysmal output by the newspapers within the conspectus of interpretative reporting. Cumulatively, 6,444 col.cms of interpretative reporting was devoted to the helicopter crash out of a total of 86457 col.cms (about six percent) space for interpretative reporting. More worrisome is the fact that none of the newspapers highlighted the subject matter in their editorial. In other words, no editorial was devoted to the issue. The imputation however is that the newspapers obviously did not consider the subject matter significant enough to deserve a space in their editorial columns. This is further marked by a complete absence of advertorials in the form of public service announcements geared towards sensitizing the public on vital issues that may illuminate or ventilate the subject matter.

Analysis, using the constant comparative technique further revealed that news content on the subject matter as reported in the three newspapers was shallow. In other words, the editorial treatment of the story lacked depth going by the fact that the reportage lacked the potential to take readers beyond the level of ordinary knowledge. Lack of depth was further manifested by the fact that most of the stories as highlighted on table 10 were completely devoid of eye witness or expert account. The implication however is that the public may be uninformed on vital perspectives regarding the crash.

The foregoing finding is a phenomenal deviation from widespread expectations that followed the passing of the FoI Act in 2011. Ordinarily, one would believe that with the unfettered access to information provided for in the FoI Act, news reports will no longer be bereft of details. The finding goes to corroborate an assertion by pundits that the FoI Act is almost becoming a document rather than a framework for journalists.

The inference therefore is that the newspapers studied demonstrated a complacent disposition towards the helicopter crash. For a country that has witnessed incessant air crashes with seemingly impotent air crash investigations, coupled with the fact that one of the most devastating crashes (Dana) occurred in 2012, it would have been expected that the press will be more pro-active in advocacy for air disasters to be matched by proper investigations and reports. Table 10 also shows that much of the advocacy for proper investigation was done by groups outside media circles. The tools for media advocacy, no doubt, are features, editorial and advertorial and these ironically were the most unutilized by the newspapers studied. Descriptively, the reportage showed a complete absence of editorial and advertorial with infinitesimal features.

In as much as the newspapers, especially Punch and The Nation, displayed similarity in terms of frequency and volume, this pattern was deduced to be unwholesome going by the fact that the reportage was marked by intensity a few days after the incident and gradually lost prominence as time went by.

\section{Table 11}

Aggregation on content categories and volume of coverage

\begin{tabular}{|c|c|c|c|c|c|c|}
\hline \multirow{2}{*}{$\begin{array}{l}\text { Content } \\
\text { Categories }\end{array}$} & \multicolumn{2}{|c|}{ Nigerian Tide } & \multicolumn{2}{|l|}{ Punch } & \multicolumn{2}{|l|}{ Nation } \\
\hline & X1 & Y1 & $\mathrm{X} 2$ & Y2 & X3 & Y3 \\
\hline $\begin{array}{l}\text { Straight } \\
\text { news }\end{array}$ & $44,253.00$ & $2,531.00$ & $182,125.00$ & $9,813.00$ & $224,640.00$ & $11,903.00$ \\
\hline Editorial & $1,326.00$ & 0.00 & $3,817.00$ & 0.00 & $5,616.00$ & 0.00 \\
\hline Features & $8,346.00$ & 0.00 & $41,607.00$ & 934.00 & $36,504.00$ & $5,510.00$ \\
\hline Advertorial & $12,060.00$ & 0.00 & $141,869.00$ & 0.00 & $64,584.00$ & 0.00 \\
\hline Total & $65,985.00$ & $2,531.00$ & $369,418.00$ & $10,747.00$ & $331,344.00$ & $17,413.00$ \\
\hline
\end{tabular}

The News papers studied, especially Punch and The Nation, did not significantly differ in category assignment and volume of coverage on the crash. Illustratively, the pattern of coverage is as shown below. See figs. $1 \& 2$ for extrapolation.

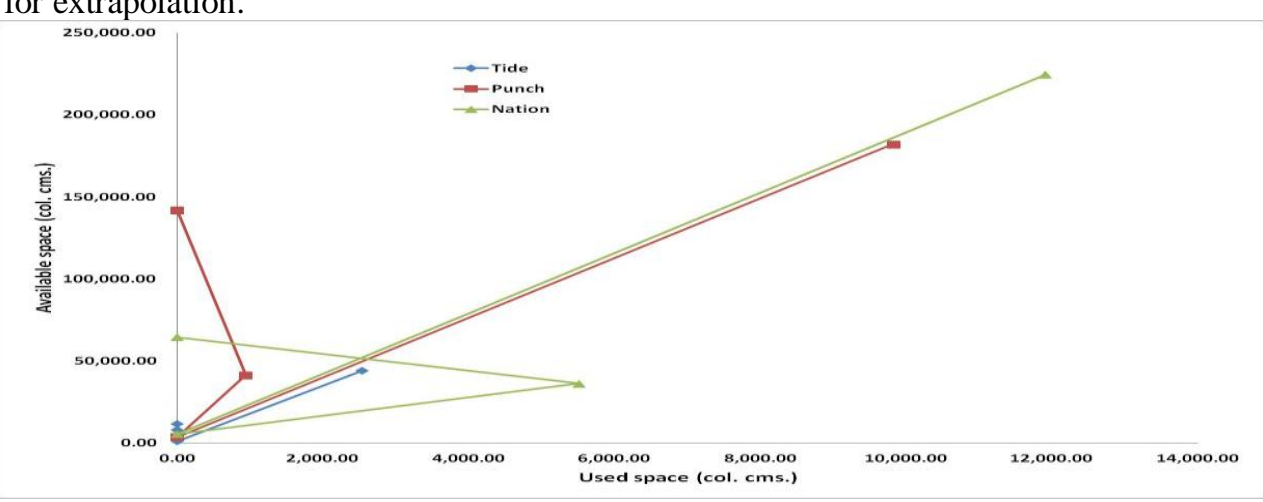

Fig. 1: Pattern of coverage on crash by Tide, Punch and The Nation newspapers The above figure shows coverage to assume the same pattern. 


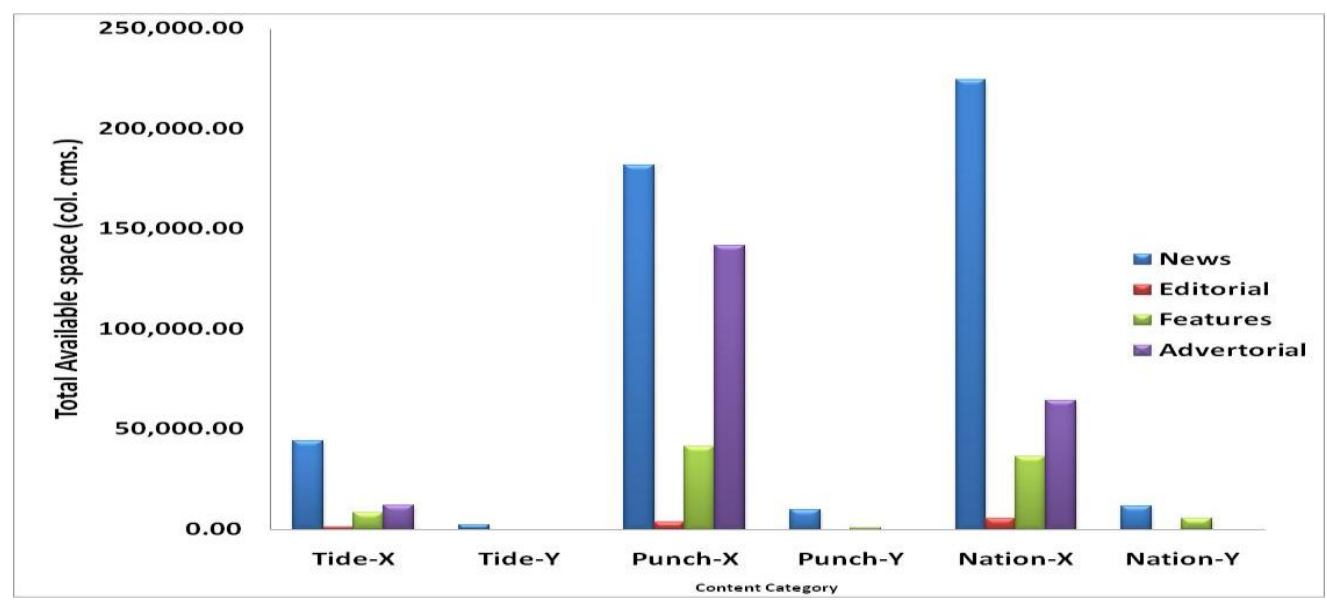

Fig 2: Bar Chart showing pattern and depth of coverage

A distillation of findings shows that the Nigerian press hardly goes beyond straight news reporting in stories of collective opinion and interests. This no doubt shows a complete disconnect with professional ideals and projects the press as seemingly abdicating its watch dog role. Mainstream journalism, in line with international best practices, requires diligent investigation and non evasive advocacy geared towards accuracy, objectivity and social constructionism. Obviously these attributes are a far cry from journalism practice in Nigeria as depicted in the coverage of Augusta 109 naval helicopter crash by Tide, Punch and The Nation newspapers.

\section{Recommendations}

1. There should be concerted efforts by the Nigerian press to increase capacities in terms of giving the news behind the news through editorials, features and advertorials so as to adequately inform readers on varied perspectives as they relate to topical issues.

2. There should be an awakening by the Nigerian press to enrich reports with depth and voices by tapping from the rich provisions of the Fol Act. This can be achieved by being creative and innovative in news gathering without necessarily being adversarial.

3. The Nigerian press should be proactively disposed towards advocacy journalism so as to champion the cause of change while giving animation and verve to its watch dog role.

4. With rise in the use of social media, the Nigerian press can excite and generate opinion on topical issues and serve as a platform for rational discourse expressed in the form of letters to the editor as well as readers reactions to op-ed pages

\section{References}

[1]. Chong, D., and Drunkman, J., (2007). Framing theory. American Review of political science. Vol.10. (pp.103-126).

[2]. D' Angelo, P. and Kuypers (2010) Doing news framing analysis: Empirical and theoretical perspectives. New York: Routledge.

[3]. Entman, R. (2007) Framing bias: Media in the distribution of power. Journal of Communication. 57(4) (pp163-173).

[4]. Kamat, P. (2011) What are the major functions of Mass Communication? (www.preservearticles.com/2012011721058/html) retrieved 07-01-13.

[5]. Kerlinger, F. (2000). Foundations of behavioral research. New York: Holt, Rinehart and Winston.

[6]. Kovach, B. and Rosentiel, T. (2006) The elements of journalism: What news people should know and the public should expect. (www.jouranlism.org/node/72.). Retrieved 14-10-13.

[7]. Kwansah-Aidoo, K. (2003) Events that matter: specific incidents, media coverage and Agenda setting in a Ghanaian context. Canadian Journal of Communication. Vol. 28. no.1 (pp.38-53).

[8]. Mc Combs, M and Estrada, G (1997) The news media and the pictures in our heads. In S. Iyengar and W. Reeves (eds). Do the media govern politicians, voters and reporters in America? (pp.237-247). Thousand oaks', CA: Sage.

[9]. Niles,R.(2011)Newsroom convergence. Online Journalism Review(www.ojr.org/gr/people/robert/2011/2/2042/utme) Retrieved 0701-13.

[10]. Orji, N. (2012,June,4).History of plane crashes in Nigeria. The Sun.(p.43)

[11]. Riffe, D., Aust, C. and Lacy, S. (1993).The effectiveness of random, consecutive day and constructed week sampling in newspaper content analysis. Journalism Quarterly. 74(4),(pp.873-882).

[12]. Rogers E, and Dearing, J. (1997) A paradigmatic history of agenda setting research in S. Iyengar and W. Reeves (eds). Do the media govern politicians, voters and reporters in America?(pp.225-236). Thousand Oaks; CA: Sage.

[13]. Shoemaker, P. and Reese, S. (1996) Mediating the message. New York: Longman.

[14]. Stromback, J., Karrison, M. and Hopamn, D. (2012). Determinants of news content: Comparing journalists' perception of the normative and actual impact of different event properties when deciding what's news. Journalism media and cultural journal. Vol.13 nos. 5 \& $6($ pp.88-103).

[15]. Wimmer, R. and Dominick, J., (2003).Mass media research. Belmont: Wadsworth

[16]. Wolfe, A. (1983) The irony of anti communism: ideology and interest in post war American foreign policy in R. Milibano, J. Saville and M. Leibman (eds). The uses of anti communism (pp.214-229). London: Merlin Press. 